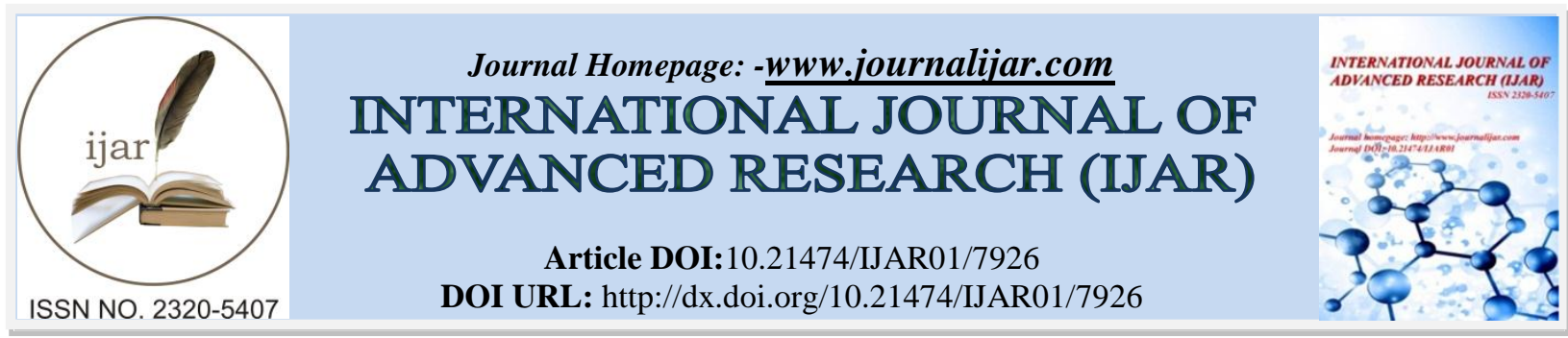

RESEARCH ARTICLE

\title{
THERAPEUTIC USE OF BOTULINUM TOXIN IN DENTISTRY.
}

\section{Lorena Cury TaniosMarrelli ${ }^{1}$, Daniele MazzucaDominelli ${ }^{1}$, Idiberto José Zotarelli Filho ${ }^{1,2}$, Leandro Moreira} Tempest $^{1,2}$ and Patrícia GaraniFernandes ${ }^{1,2}$.

1. University Center North Paulista (Unorp) Dental School - São José do Rio Preto - SP, Brazil.

2. Post Graduate and Continuing Education (Unipos), Department of scientific production, Street Ipiranga, 3460, São José do Rio Preto SP, Brazil.

\section{Manuscript Info}

\section{Manuscript History}

Received: 15 August 2018

Final Accepted: 17 September 2018

Published: October 2018

Keywords:-

Botulinum toxin, therapeutic use, dentistry, dentist..

\begin{abstract}
Botulinum toxin is a versatile therapeutic agent that has become the most successful non-surgical method in Brazil for being effective in various dental treatments. The main purpose of this study is the therapeutic use of botulinum toxin in Dentistry. In order to satisfy the objectives of this study, a literature review was held. It is known that the dentist has extensive knowledge of the anatomy of head and neck, so he is highly skilled to treat pathologies regarding this part of the oral cavity and face with the botulinum toxin since he possesses specific training and knowledge about its use. If executed by a skilled professional, we can expect to obtain safe and conservative results, providing comfort to the patient.
\end{abstract}

Copy Right, IJAR, 2018,. All rights reserved.

\section{Introduction:-}

Botulinum toxin is a gram-positive anaerobic catalytic protein that acts on nerve endings. It is presented as a hydrophilic, vacuum-stored, sterile and stable powder, the most commonly used type A [1].

When performs intramuscular injection of botulinum toxin type A (BTA), this neurotoxin will block the release of acetylcholine at the muscular nerve terminals. Injection of BTAis performed at the target site, promoting temporary muscle relaxation [2]. Proper use guarantees a decrease in contracture without causing complete paralysis in a less invasive, rapid and effective manner for various therapeutic treatments in dentistry [3]. The results are obtained on average from 2 to 5 days (lasting 2 weeks) and last, on average, from 6 weeks to 6 months [3].

The reversal of paralysis may occur in two ways: 1) For the formation of "neural budding" of axonal shoots, reinnervation and formation of new smaller terminal plates with temporary muscular reinnervation; 2) By the regeneration of the coupled proteins of the acetylcholine vesicles [4].

Therefore, the study addressed the use of BTA as a conservative therapeutic option in cases of bruxism, masseter muscle hypertrophy, temporomandibular dysfunctions, gingival smile harmonization, postoperative surgical implants and, finally, in cases of associated sialorrhea to patients with neurological disorders. 


\section{Methods:-}

In the present study, the literature review method was used, where through existing studies and information, results of already completed researches are gathered and synthesized. The literature review of this review was carried out through the search of scientific articles available in Google, SciELO-ScientificEletronic Library Online and in the journal ActaFisiátrica through the keywords: Botulinum Toxin, Dentistry, Applications. Twenty previously published papers were selected and used as a reference.

\section{Literature Review and Discussion \\ Bruxism}

Bruxism is a disease that affects the functional muscular masticatory activity, occurs involuntarily and unconsciously, where the patient compresses the teeth excessively. It is known that bruxism is a disease with broad etiology and the severity of the damage tends to vary from individual to individual [5]. Bruxism is a habit that can cause tooth wear and temporomandibular joint changes, when treated late, can subject the patient to a possible dislocation, and even degenerative arthritis of the temporomandibular joint [5].

The application of BTA is an alternative treatment for those patients with bruxism, where an intramuscular injection of the substance is carried out in the masseter muscle and in the anterior ventricle of the temporalis in order to inhibit the release of acetylcholine in the nerve terminals, thus promoting the reduction of Muscular contraction. Some studies have also found pain relief and masticatory sensitivity [6].

Botulinum toxin has proven to be effective in the treatment of bruxism, mainly because it is a therapeutic option that will not depend on the patient's collaboration in following the treatment, as occurs in cases of nocturnal use of intraoral plaques [7].

\section{Masseter muscle hypertrophy}

Masseter muscle hypertrophy is a benign condition of unknown origin that may be congenital or acquired, unilateral or bilateral where there are rare reports of pain, but when present it is well defined and localized [8]. The etiology of masseter muscle hypertrophy can be induced by mandibular retrognathia, malocclusions, temporomandibular joint dysfunctions; or to parafunctional habits such as bruxism [8].

The diagnosis is established by an increase in the volume in the region of the masseter muscle and in the region of the mandibular angle [9]. By causing a facial remodeling, it generates an aesthetic discomfort for the patient [9]. When using BTA as a therapeutic option in cases of masseter muscle hypertrophy, long-term hypotrophy occurs in the muscle chosen for the application, it is a more conservative therapeutic option when compared to surgical techniques, which can lead to numerous complications [10].

\section{TMJ dysfunctions}

The temporomandibular joints (TMJ) are formed by right and left joint complexes, they are classified as a complex bicondylar synovial diarthrosis [11]. The algic process of TMJ is difficult to identify because it is a pathology with a multifactorial origin where there is no agreement on an exact pathophysiology of the disease [11].

The pain syndrome of the TMJ may be a consequence of spasms of the masticatory muscles that, when they are in fatigue or continuous contraction, trigger the painful process, so, with BTA, it was found a way to relieve the pain because it has myorelaxant properties [12].

BTA is injected into the masticatory muscle responsible for the triggering alteration of the TMJ pain process, the main being the masseter, temporal and lateral pterygoid muscles [12]. Muscles chosen will be those with the highest palpation volume [13]. Another alternative is the use of complementary tests such as electromyography, which is responsible for assessing the hyperactivity of the muscles. BTA will act by relaxing the masticatory muscles and relieving pain, so the result will be a balance of mandibular functions [14].

\section{Gingival smile}

The gingival smile is characterized by exposure of $3.0 \mathrm{~mm}$ or more of gingival tissue during the smile, it is a hyperfunction of the muscles involved [15]. The gingival smile is a major complaint of patients because it is a nonaesthetic situation that can psychologically and socially affect some patients, impairing their self-esteem [15]. 
The application of BTA in the smile muscles is a more conservative therapeutic option that produces harmonic and pleasant effects. The application technique may vary depending on the classification of the gingival smile [16]. In the case of an anterior gingival smile, the BTA is applied laterally to the nose wing (conventional technique). In the case of a posterior gingival smile, the application of BTA is at the point of greatest contraction of the nasolabial sulcus during the smile activity and at a second point, $2 \mathrm{~cm}$ laterally to the first, at the level of the Trágus line. In the case of a mixed gingival smile, both techniques described above are used [16].

Although the application of BTA in the muscles involved in the smile has a temporary effect, the application is an effective, fast and safe option when compared to surgical procedures [17]. Another treatment option is to associate BTA with respective gingival surgery, where excellent results and a great improvement in the condition are obtained [17].

\section{Post-operative implant surgery}

Studies have analyzed the therapeutic and prophylactic action of BTA in patients who are in the process of implants. It has been shown to be a great ally for implants with immediate loading - in addition to being safe and effective, by reducing masticatory forces, it will act in the preservation of stability, favoring osseointegration [18].

\section{Reduction of sialorrhea}

The sialorreiais characterized by excessive salivation and generates to its bearer clinical and functional complications, generating a negative impact on the quality of life of the patient [19]. It usually affects patients with cerebral palsy, Parkinson's, ALS (amyotrophic lateral sclerosis). The application of BTA proved to be an acceptable treatment approach, where the patients presented a reduction in the frequency of excessive salivation and its production [19].

In the case of patients with neurological diseases the application of BTA in the central point of the salivary glands obtained positive results. A physical, psychological and social improvement was observed. There is still a diversity regarding technique, dose and number of application points in the glands, selection of glands to be treated and side effects, however, the application of BTA is a less invasive procedure when compared to surgical procedures and anticholinergic drugs, besides of not causing significant adverse effects [19].

Considering the literature review carried out in the present study, it was observed that most authors agree that the use of BTA produces a beneficial effect and is considered an advance in the therapeutic alternatives of several pathologies. It is important to note that BTA has shown to be effective in several chronic and painful disorders where pharmacotherapy could cause undesirable side effects [20].

BTA is increasingly used in dentistry because it is a safe and well tolerated option. Intramuscular injections should always observe areas of muscle hyperactivity [20].

Studies on BTA should be continued, as the therapeutic use of BTA is a recent practice in the market, there is a lack of information on long-term side effects [20]. However, it is concluded that the use of BTA contributes to the improvement of the quality of life of many patients and that no alternative in the search for relief and solution of symptoms should be overlooked. It is imperative that the operator has specific training and knowledge of its use to be successful in treatment [20].

\section{Conflict of interests}

There is no conflict of interest between authors. 


\section{References:-}

1. Amantea DV, Novaes AP, Campolongo GD, Pessoa de Barros T. A utilização da toxina botulínica tipo A na dor e disfunção temporomandibular. V. 3, n. 10, p. 170-173, Abr/Jun. 2003.

2. Bratz PDE, Mallet EKV. Toxina botulínica tipo A - abordagens em saúde. V. 8, n. 15-16, 2015.

3. Colhado DCG, Boeing LB, Ortega LB. Toxina botulínica no tratamento da dor. V. 59, n. 3, p. 366-381, Mai/Jun. 2009.

4. Dall'Antonia M, Netto RMO, Sanches ML, Guimarães AS. Dor miofascial dos músculos da mastigação e toxina botulínica. V. 14, n. 1, p. 52-57, Jan/Mar. 2013.

5. Filho AFO, Silva GA, Almeida DMX. Aplicação da toxina botulínica no tratamento da sialorreia em pacientes com esclerose lateral amiotrófica: revisão de literatura. V. 14, n. 3, p. 431-434, 2016.

6. Gaeta VB, Bazilio MTM, Neto AR, Pedron IG. Sorriso gengival: complementação do tratamento conjugado ortopedia funcional e ortodontia pela associação terapêutica entre toxina botulínica e cirurgia gengival ressectiva. V. 23, n. 45-46, p. 19-28, 2005.

7. Ihde SKA, Konstantinovic VVD. The terapeutic use of botulinism toxin in cervical and maxillofacial conditions: an evidence based review. V. 104, n. 2, p. 1-11, 2007.

8. Maio MM, Soares FD. Toxina botulínica em paralisia facial: um tratamento minimamente invasivo para redução da hipercinesia muscular da região perioral contralateral. V. 11, n. 1, p. 1-10, Jan/Mar. 2007.

9. Manrique D. Aplicação da toxina botulínica tipo A para reduzir a saliva em pacientes com doenças neurológicas. V. 3, n. 3, p. 174-178, 2005.

10. Marciano A, Aguiar U, Vieira PGM, Magalhaes SR. Toxina botulínica e sua aplicação na odontologia. V. 4, n. 1, p. 65-75, 2014.

11. Pedron IG. Cuidados no planejamento para aplicação da toxina botulínica em sorriso gengival. V. 26, n. 3, p. 250-256, Set/Dez. 2014.

12. Pedron IG. Utilização da toxina botulínica tipo A associada à cirurgia gengival ressectiva: relato de caso. V. 24, n. 3, p. 35-39. Set/2014.

13. Pedron IG. Aplicação da toxina botulínica associada a clinica integrada no tratamento do sorriso gengival. V. 32, n. 4, p. 365-369, 2014.

14. Senise IR, Marson FC, Progiante PS, Silva CO. O uso da toxina botulínica como alternativa para o tratamento do sorriso gengival causado pela hiperatividade do lábio superior. V. 23, n. 3, p.104-110, Jul/Set. 2015.

15. Sevilha FM, de Barros TP, Campolongo GD, Neto LB. Toxina botulínica tipo A, uma alternativa para tratamentos odontológicos. V. 21, n. 2, p 12-17, 2011.

16. Schlosser DV, Santos MA, Santos PG, Durscki JRC, Arruda EP, Assad RA, Leão BLC, Marques FR. Uso da toxina botulínica na odontologia. V. 15, n. 2, p. 26-34, 2016.

17. Sposito MMM. Toxina botulínica tipo A: mecanismo de ação. V. 16, n.1, p. 25-37, 2009.

18. Sposito MMM, Teixeira SAF. Toxina botulínica tipo A para tratamento da sialorreia: revisão sistemática. V. 20, n 3, p. 147-151, 2013.

19. Sposito MMM, Teixeira SAF. Toxina botulínica tipo A para bruxismo: análise sistemática. V. 21, n. 4, p. 201-204, 2014.

20. Teixeira SAF, Sposito MMM. A utilização da toxina onabotulinica A para o bruxismo: revisão de literatura. V. 70, n. 2, p. 202-204, Jul/Dez. 2013. 